\title{
Corporate Social Responsibility as Strategy for Environmental Preservation and Control of Youth Restiveness: The Experience from South-West Nigeria
}

\author{
Eniola. A. Sokefun ${ }^{1} \&$ Oluseyi. O. Oduyoye ${ }^{2}$ \\ ${ }^{1}$ Department of Business Administration, Mountain Top University, Ogun State, Nigeria \\ ${ }^{2}$ Department of Business Administration and Marketing, Babcock University, Ilishan Remo, Ogun State, Nigeria \\ Correspondence: Eniola. A. Sokefun, Department of Business Administration, Mountain Top University, Ogun State, \\ Nigeria.
}

Received: November 2, 2017

doi:10.11114/bms.v4i2.3281
Accepted: March 28, $2018 \quad$ Online Published: May 16, 2018

URL: https://doi.org/10.11114/bms.v4i2.3281

\begin{abstract}
Corporate social responsibility, a concept that has been around for well over 50 years has become prominent again recently. It is discussed in the context of organizations been socially responsible for the environment in which they operate. The strategy of impacting on these communities is referred to as corporate social responsibility. The study was designed to assess the strategies adopted by selected organizations in the Food and Beverage Industry in South-West Nigeria to preserve the environment in which they operate and control youth restiveness.

Survey research design was adopted. The population consisted of communities in Lagos, Ogun and Osun States, namely: Ikeja, Apapa, Otta, Imagbon and Ilesa. A sample size of 600 (six hundred) respondents was drawn from the communities through the accidental and purposive sampling methods. The questionnaires were validated and their reliabilities confirmed through the analysis which resulted in Cronbach Alpha value of 0.957. Data collected were analysed using descriptive statistics, correlation and multiple regression.

Findings revealed a significant positive relationship between corporate social responsibility, environmental preservation and the control of youth restiveness in the communities studied

The study concluded that where firms get involved in corporate social responsibility, tendency is that communities will benefit immensely, it will lead to the enhancement of lives and general welfare of individuals, groups and society at large. It will equally assist in poverty alleviation. The study recommended that corporate social responsibility policies and practices should be more regulated and the need for the development of a legal framework for corporate social responsibility in Nigeria
\end{abstract}

Keywords: corporate social responsibility, environmental preservation, poverty alleviation, society, organization, sustainable development goals, industrial revolution

\section{Introducation}

\subsection{Background to the Study}

Society exists for the benefit of human beings to utilize the abundant resources within it to enhance lives. In this process, continuous interactions exist between man and its environment which may result in both positive and negative consequences to the environment and man.

From the time of creation, man had the responsibility of nurturing, protecting and preserving the environment in order to continually derive favourable benefits from the environment. It is for this reason and many more, that organizations partner with government and their host communities to preserve, protect, enhance lives and develop these communities through their strategic intervention referred to as corporate social responsibility.

Corporate social responsibility has been recognised as one of the main constructs that in a coherent manner strongly enhance and to a large extent, where it is successfully implemented strengthens the existing relationship between an organization and the community or society where it operates (Oh and Park, 2015). 
In the business environment of developed countries, there is a constant partnership between organizations, government and communities to ensure that societal development goals are achieved through concerted efforts and resources of organizations, communities and government, particularly as organizations are open systems and given their numbers in society.

Since organizations produce goods and services within the communities, they cannot afford to operate in failed society. In other words, they must strive to be good citizens and exhibit behaviours that are socially and environmentally responsible. Environmental responsibility connotes, ensuring that during the course of their operations, organizations put structures in place to preserve the environment, by managing waste, emissions, material recycling, effluence and other harmful materials that can affect the lives of citizens in the communities (Maldonado-Guzman, Pinzo-Castro and Lopez-Torres, 2016).

When firms are socially responsible, they are involved in social activities, support to education, cultural activities, healthcare and employment creation, all of which will enhance the lives of the citizens.

Corporate social responsibility has turn to be part of business strategy for corporate development, sustenance and survival since its inception in the early 1930s. For the realization of sustainable development, organizations in the process of production, must adhere to concrete economic values in the economic, political, technological, cultural and be determined to operate, by mitigating environmental risks and improving socio-economic well-being of the citizenry and through this, control particularly youth restiveness, where such environment is vulnerable, meet shareholders' expectations and promote inclusive growth (Oginni and Omojowo, 2016).

Although, in Nigeria, corporate social responsibility is voluntary, as compared to what is obtainable in developed countries in Europe and America. But when a consideration of the distinctive motto of corporate social responsibility as put forward by Prahalad (2005) which referred to the short and snappy phrase corporation can "do well by doing good" is considered, it is imperative to stress that corporate social responsibility has become a company's commitment to minimizing or enhancing any harmful effects firms' operations may cause it host communities and invariably, maximizing long-term beneficial impact on society (Mohr and Webb, 2005).

Corporate social responsibility is a strategy that combines three separate agenda namely: sustainability, corporate accountability and corporate governance.

Sustainability implies the regular and enhanced process of balancing the social, economic and environmental areas of the world to avoid threatening long-term survival, corporate accountability deals with organization's credibility and ability to manage resources properly at all time and corporate governance dealing with the manner an organization is run with transparency and trustworthiness (Whelan, 2012; UNO 2013; Eccles, Ioannou and Serafeim, 2013).

\subsection{Statement of the Problem}

Nigeria with an emerging economy has witnessed increased influx of organizations from different parts of the world, particularly as a result of her large market. This brought about the establishment of many multinational firms, local firms and small enterprises in the nation.

Unlike their counterparts in other parts of the world, firms in Nigeria see corporate social responsibility as voluntary, an unnecessary and additional cost, which should be avoided as much as possible.

Aside from the above, even with many regulatory bodies monitoring the operations of firms in Nigeria, the monitoring is very weak and the implementation of the policies to make organizations friendly to the communities where they operate is equally poor.

Furthermore, with the current global recession, of which Nigeria shares much of its negative impact, coupled with gross mismanagement of funds at different levels of government, societal development is at its very low level, with individuals and groups in communities looking up to viable multinational companies for solace in terms of community development and citizens' well-being.

Many organizations operate in their host communities without considering giving back to the communities that made them. Besides, some of these organizations destroy the environment, render individuals and groups inactive, increase unemployment, poverty and crime in the communities where they operate, as a result of complete neglect of the communities,

To this end, the study was conducted to sensitize multinational companies in other parts of Nigeria, to the need to contribute meaningfully to the development of the communities where they operate and in particular ensure that proper strategic decisions are made to impact positively on the lives of stakeholders through corporate social responsibility. 


\subsection{The Objectives of the Study}

The main objective of the study is to determine how corporate social responsibility can be deployed as a strategy to preserve the environment and in particularly control youth restiveness. However, the study aimed to achieve the following specific objectives

(i) To determine the effects of environmental responsibilities on environmental preservation.

(ii) To evaluate the impact of social responsibilities on environmental preservation.

(iii) To assess the effects of economic responsibilities on the control of youth restiveness.

(iv) To examine the role of philanthropic responsibilities on the control of youth restiveness.

\section{Literature Review}

\subsection{Corporate Social Responsibility Defined}

Many scholars claimed that corporate social responsibility officially took it root in the 1930s. However, underlying socially responsible ideals can be traced back to the mid-1800 during the early stage of Industrial Revolution (Crane and Matten, 2009). With the explosion of factory production, it was clear these establishments started their operations in a way that most would consider to be socially harmful, with horrible working conditions, child labour, lack of minimum wages, poor environmental management and many other actions by the firms, which were inimical on workers and communities at large (Crane and Matten, 2009).

Corporate social responsibility has been defined variously, which points to differing views regarding the role of business in society (Clarkson, 1995; Lantos, 2001). Within the literature, there exist three discernible 'schools of thought' and practice about corporate social responsibility. These are the Neo-liberal, Neo-Keynesian and Radical Political Economy.

Neo-liberal writers tend to see corporate social responsibility as the fundamental adoption of a set of voluntary policies, codes and guidelines, initiated and driven by the corporation. They situate it into the company's management of the economic, social and environmental inputs of its activities. The Neo-liberal discourse around corporate social responsibility generally shares the view articulated by Milton Friedman in the New York Times of September 13, 1970 that "there is one and only social responsibility of business, to use its resources and engage in activities designed to increase profits, so long as it stays within the rules of the game, which is to engage in open and free competition without deception or fraud". This school of thought believe that corporate social responsibility is an unreasonable intrusion into and restriction on business primary purpose.

On the other hand, the Neo-Keynesian approach to corporate social responsibility utilized a wider conception that more clearly recognises the active role of corporations' 'stakeholders' and perhaps the state. They conceptualize corporate social responsibility as an approach adopted voluntarily by firms and without external regulation by stakeholders or the state. They believe that it is a concept whereby companies integrate social and environmental concerns in the business operations and their interactions with their stakeholders, but on a voluntary basis. They see it as a company's commitment to operating in an economically, socially and environmentally sustainable manner, while recognising the interests of its stakeholders, including investors, customers, employees, business partners, local communities, the general environment and society at large.

The third school of thought, the Radical Political Economy, takes a more critical stance on corporate social responsibility. The approach possesses normative views about the role of business in general and corporation in particular in society. The approach begins with the consideration of the existence of corporate power in global, national and local economies. Multinational companies in particular are considered to have enormous power, which is often wielded ruthlessly in their own interest and frequently at the expense of society and environment. They see advocates of voluntary corporate social responsibility as lacking a critical political economy analysis and therefore failing to fully understand and incorporate a realistic view of the power structure that exist in society and its economic environment. The school viewed many of the policies and practices that have been developed to promote corporate social responsibility as naïve, ineffective and inadequate.

The approach is sceptical about the effectiveness of programmes, concerned that self-regulatory and voluntary corporate social responsibility policies are frequently deliberately designed by firms to shift attention away from external regulation and control of corporate behaviour and power to disguise and legitimize other activities that are socially and environmentally destructive (Okafor, Hassan and Doyin-Hassan, 2008; Olawari and Paki, 2011).

Specifically, corporate social responsibility can be defined as "the policy and practice of corporation's social involvement over and beyond its legal obligations for the benefits of society at large" (Enderle and Tavis, 1998). It is viewed as the corporate actions, whose purpose is to satisfy social needs. Carroll (2008) viewed corporate social 
responsibility as "the private contributions to society's economic, human resource and a willingness on the part of business to see that those resources are utilized for broader social ends"

Furthermore, Strandberg (2009) defined the concept as "the balanced integration of social and environmental considerations into business decisions and operations of organization". The scholar believed that corporate social responsibility has a significant role it plays in motivating, developing and retaining staff, as well as ensuring sustainable community development.

Maldonado-Guzman et al (2016) viewed the concept as a strategy by organization particularly the Small and Medium Enterprises to increase its market participation, obtain major level of company performance and invariably impact positively on their operating environment. Benabou and Tirole (2009) adopted a simple standard definition as "the situation where an organization sacrifices profits for social interest". For these scholars, for there to be a sacrifice, the firm must go beyond its legal and contractual obligations on a voluntary basis, thereby embracing a wide range of behaviours, like been employee friendly, environmentally friendly, mindful of ethics, respectful of communities where they operate and being investor friendly.

AbdRahim, Jalaludin and Tajuddin (2011) defined corporate social responsibility as "treating the stakeholders of a firm ethically or in a responsible manner". While Muhammad, Naseer, Sharez and Mehfooz (2012) viewed corporate social responsibility as broadly grounded in an understanding of business being part of society, having important effects on environmental issues, eradication of poverty, employment creation and friendly labour practices, environmental protection, education and human development. Corporate social responsibility has become so important that many organizations have re-branded their core values to include social responsibility.

\subsection{What Is a Strategy?}

Strategy can be defined as the matching of the activities of an organization to the environment in which it operates. This is sometimes known as search for strategic fit. Strategy involves developing decisions that will impact positively on the growth and survival of an organization. Strategic decisions therefore are concerned with and affect the long-term direction of an organization, they are formulated to achieve some advantages for the organization and they cover the scope of an organization's activities and to a large extent affect operational decisions.

Strategy is the direction and scope of an organization over the long term, which achieves advantages for the organization through its configuration of resources within a changing environment, to meet the needs of markets and fulfil stakeholders' expectations.

The strategy of an organization will be affected not only by environmental forces and resources availability, but also by the values and expectations of those who have power in and around the organization. This extends to those whose attitudes and beliefs have influence on an organization.

It was observed that multinational organizations in the Food and Beverage industry deliberately and consciously developed corporate social responsibility strategies as a means of competitive advantage and to give back to the societies that made them.

\subsection{Measures of Corporate Social Responsibility}

Many variables/components serve as measurements of corporate social responsibility established around the world. This study used four most influential components which include: Economic, Social, Environmental and Philanthropic. Economic is a concept that embraces the relationship between policies, decisions, institutions, theories and choices that affect the production of goods and services. Economic refers to the profits, cost, saving, economic growth, research and development in an organization. The profit characteristic needs to be considered by the firm as the real economic benefit of the society. When economic aspects are integrated in social aspects, they come up with business ethics, fair trade and workers' rights, which help to maintain social and economic accountability and have a balance between economic and social elements (Bahadur and Waqqas, 2013). However, economic and social aspects cannot be separated.

Social aspects refer to the standard of living, education, community and equal opportunity, healthcare, improvement in infrastructure, all within the society. These aspects focus on social responsibility. Environmental aspects, which include natural resources use, environmental management and pollution prevention of air, water, land and waste. The ultimate goal here, is to do no damage to the environment, as well as supervising and cautiously utilizing energy and resources, at the same time, decreasing manufacturing wastes and contamination materials before disposal, so that the environment is safe and therefore properly preserved.

It is observed that multinational firms pursue environmental initiatives that are viewed as an option to induce economic stimuli, while achieving solid corporate social responsibility goals. However, some firms struggle to improve on environmental performance in order to reach regulatory framework, market demand and search for competitive 
advantage. Environmental management is therefore associated with repetitive matters like reduction of pollution, biodiversity, waste management, noise and energy consumption (Yusoff and Adamu, 2016).

Finally, philanthropic represents individuals and group empowerment and enhancement of lives by the firms in the community where business operations are conducted or carried out. A key stakeholder to any business is the community where the firm operates. Generally, philanthropic activities include charitable donations or sponsorship in which the firms promote economic development. For instance, efforts made to improve local infrastructure, community engagement and development, social welfare, security, community healthcare and education are considered within this framework.

\subsection{Theoretical Review}

The research adopted the Stakeholders Theory, as it is found to be the most suitable theory, given its relevance and relationship between the needs for the organizations to take into consideration the stakeholders of the firms, where they operate and the needs for these organizations to contribute meaningfully to socio-economic, cultural and environmental development of their communities and through this process, able to control and prevent youth restiveness, which can be inimical to their smooth operations, as it is found in the Niger Delta region in Nigeria. More importantly, the theory was adopted by many scholars in their studies of corporate social responsibility among which are (Amole, Adebiyi and Awolaja, 2012; Akanbi and Ofoegbu, 2012; Osemede, 2012; Olawari and Paki, 2011, Sokefun, 2015).

\subsection{Stakeholders Theory}

One of the important differentiating factors in the approach of Neo-Keynesian theorists on corporate social responsibility, in contrast to the Neo-Liberal view, is the argument that in order for corporate social responsibility to be effective and meaningful, the interests of a range of stakeholders other than shareowners need to be taken into account by corporations. As against the neo-liberal conception of managerial obligations, where the social responsibility of business is to maximize profit. The stakeholders' theorists hold that business organizations must play active social role in society where they operate.

Stakeholders' theory is based on the notion developed by Freeman (1984), that corporations consist of various stakeholders beyond their own shareholders and that they should be managed with these groups in mind. Freeman stated that stakeholders are " groups and individuals who can affect or are affected by, the achievement of an organization's mission.

First, shareholders are the owners of corporations and managers who do not have the right to act on their own preferences, to make discretionary decisions or to use company's resources to further social goals, which cannot be shown to be directly related to profits. Second, companies' role is to produce wealth and pursuing socially responsible objectives may impair their performance in that role, interfering with efficient resource allocation.

However, stakeholder theory is based on the notion that beyond shareholders, there are several agents with an interest in the actions and decisions of companies. Stakeholders are groups and individuals who benefit from or are harmed by and whose rights are violated or respected by corporations' actions. Each of the stakeholders groups has a right, not to be treated as a means to an end and therefore should and most participate in determining the future direction of the company, which they have a stake. Examples of stakeholders are shareholders, consumers, suppliers, employees, government, local community and non-profits organizations.

A stakeholder is " any individual or group whose role-relationship with an organization helps to define the organization, its mission, purpose or its goals and is vital to its development, functioning, survival and success or well-being of the organization, its services and in all, is affected by the organization and its activities (Werhane and Freeman, 1999). A fundamental characteristic of stakeholders' theory is therefore to attempt to identify individuals and groups that states and corporations are accountable to.

The interactions between organizations and their stakeholders are the essence of the theory and in consequence, terms like " participation", " inclusion", " voice", " involvement" and "partnership", are common in stakeholders literature. These terms have been put in the same basket named " stakeholders dialogue", to describe the involvement of stakeholders in decision-making process that concern both social and environmental issues (Amole, Adebiyi \& Awolaja, 2012).

Therefore, from a stakeholders' theory, corporate social responsibility is analysed in terms of a company meeting the demands of its multiple stakeholder groups and companies seeking to satisfy their demands, as an unavoidable cost of doing business.

The perspective stresses that corporate social responsibility becomes the ability of the company to meet or exceed stakeholders' expectations regarding social issues. It is a strategy for environmental preservation and control of youth 
restiveness, granted the responsible behaviours of corporations in the communities where they produce goods and services and more importantly having positive impacts on the lives of individuals and groups in the communities.

Table 1.1. List of Corporate Stakeholders

\begin{tabular}{|c|c|c|c|}
\hline Group & Contributions & Relationship & $\begin{array}{l}\text { Corporate } \\
\text { Obligations }\end{array}$ \\
\hline Shareholders & Financial capital & Primarily legal & $\begin{array}{l}\text { Dividends and/or increase in } \\
\text { capital value consistent with other } \\
\text { obligations }\end{array}$ \\
\hline al Investors & lancial capital & y Contractual & Repayment of Interest and capital \\
\hline & Management oversight & Legal and co & Compensation \\
\hline Employees & $\begin{array}{l}\text { Intellectual and physical } \\
\text { labour, experience, } \\
\text { initiative and commitment }\end{array}$ & $\begin{array}{l}\text { Contractual (individually and } \\
\text { collectively) }\end{array}$ & $\begin{array}{l}\text { Fair compensation and conditions } \\
\text { of service, respect for human } \\
\text { rights, safety and employment } \\
\text { security. }\end{array}$ \\
\hline $\begin{array}{l}\text { Customers } \\
\text { consumers }\end{array}$ & $\begin{array}{l}\text { Intermediate and ultimate } \\
\text { demand for products and } \\
\text { services }\end{array}$ & $\begin{array}{l}\text { May be direct and } \\
\text { contractual or mediated } \\
\text { through retailers. Also } \\
\text { subject to legal regulation }\end{array}$ & $\begin{array}{l}\text { Duty of care, fair competition and } \\
\text { trade practices. }\end{array}$ \\
\hline Suppliers & Business inputs & Primarily contractual & $\begin{array}{l}\text { Payment for inputs, fair } \\
\text { competition and trade practices. }\end{array}$ \\
\hline $\begin{array}{l}\text { Local communities in } \\
\text { which company } \\
\text { operates }\end{array}$ & $\begin{array}{l}\text { Local security, conducive } \\
\text { business environment }\end{array}$ & $\begin{array}{lcr}\begin{array}{l}\text { Primarily } \\
\text { involves } \\
\text { regulations }\end{array} & \begin{array}{c}\text { informal } \\
\text { some }\end{array} & \begin{array}{r}\text { and } \\
\text { local }\end{array} \\
& & \end{array}$ & $\begin{array}{l}\text { Compliance with laws, taxation, } \\
\text { responsible use of environmental } \\
\text { carrying capacity and support for } \\
\text { community. }\end{array}$ \\
\hline $\begin{array}{lr}\text { State/ } & \text { national } \\
\text { communities } & \text { in } \\
\text { which } & \text { company } \\
\text { operates } & \\
\end{array}$ & $\begin{array}{l}\text { State/national security, } \\
\text { licence to operate }\end{array}$ & $\begin{array}{l}\text { Implicit in licence to operate, } \\
\text { legal regulation }\end{array}$ & $\begin{array}{l}\text { Compliance with laws, taxation, } \\
\text { responsible use of environmental } \\
\text { carrying capacity and support for } \\
\text { community }\end{array}$ \\
\hline Global Community & $\begin{array}{l}\text { International } \\
\text { environmental } \\
\text { capacity }\end{array} \quad \begin{array}{r}\text { trade, } \\
\text { carrying }\end{array}$ & $\begin{array}{l}\text { Almost wholly implicit, } \\
\text { mediated through national } \\
\text { governments }\end{array}$ & $\begin{array}{l}\text { Responsible use of Greenhouse } \\
\text { and other global environmental } \\
\text { carrying capacity, fair trading } \\
\text { conditions. }\end{array}$ \\
\hline
\end{tabular}

Source: Carroll 2008

\section{Methodology}

The study adopted the survey research method with the population of the communities sampled as One Million, Three Hundred Thousand and Three Hundred and Eight (National Population Commission, 2006). This was in line with studies previously conducted by Olawari and Paki (2011), Okafor et al (2008), Oginni and Omojowo (2016), Gabriela and Daniel (2013), Bahadur and Waqqas (2013) and Amole et al (2012). A sample of Six Hundred (600) respondents was drawn from the communities through the accidental and purposive sampling methods.

The companies involved in CSR in these communities that are of interest to the researchers are the Multinational Firms in the Food and Beverage Industry. The communities were in Lagos, Ogun and Osun States, namely: Ikeja, Apapa, Otta, Imagbon and Ilesha.

\section{Research Model}

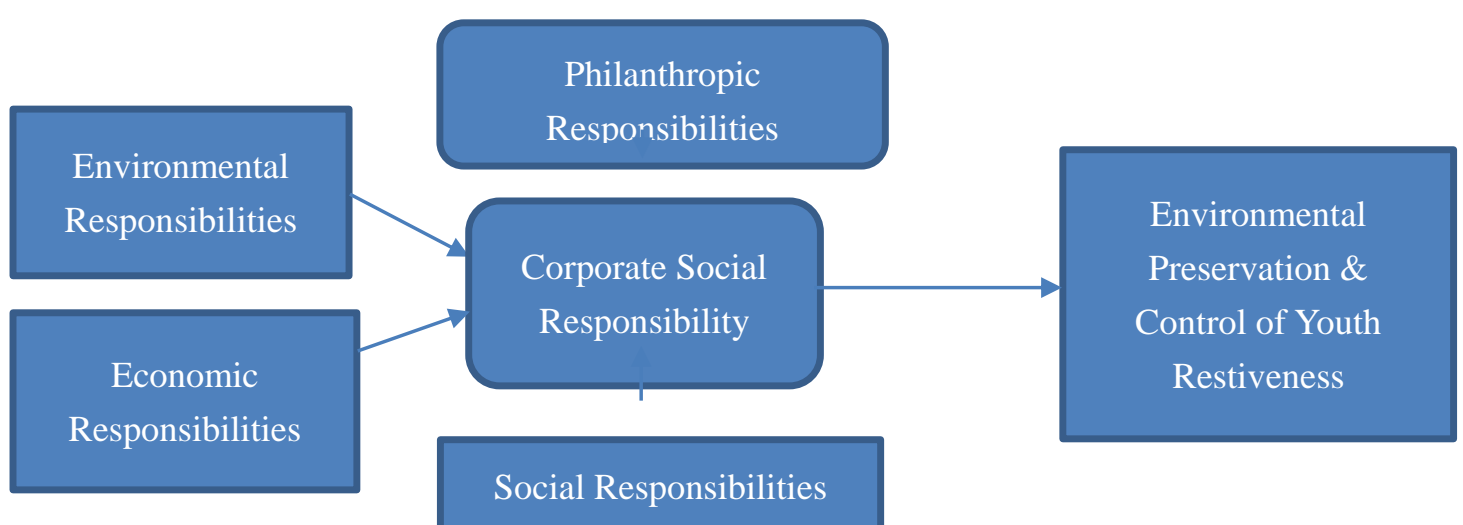

Figure 1.1. Represents the Research Model 


\section{Results and Discussion}

Table 1.2. Correlation Matrixes for Explanatory Variables

\begin{tabular}{l|l|l|l|l|l|l}
\hline & $\begin{array}{l}\text { Environ- } \\
\text { mental } \\
\text { Responsi- } \\
\text { bilities }\end{array}$ & $\begin{array}{l}\text { Social } \\
\text { Responsi } \\
\text {-bilities }\end{array}$ & $\begin{array}{l}\text { Economic } \\
\text { Responsi-b } \\
\text { ilities }\end{array}$ & $\begin{array}{l}\text { Philanthropic } \\
\text { Responsibilities }\end{array}$ & $\begin{array}{l}\text { Environmental } \\
\text { Preservation }\end{array}$ & $\begin{array}{l}\text { Control } \\
\text { Youth } \\
\text { Restiveness }\end{array}$ \\
\hline $\begin{array}{l}\text { Environmental } \\
\text { Responsibilities }\end{array}$ & 1.000 & .747 & .711 & .768 & .846 & .793 \\
\hline $\begin{array}{l}\text { Social } \\
\text { Responsibilities }\end{array}$ & .747 & 1.000 & .747 & .822 & .796 & .846 \\
\hline $\begin{array}{l}\text { Economic } \\
\text { Responsibilities }\end{array}$ & .711 & .783 & 1.000 & .796 & .746 & .844 \\
\hline $\begin{array}{l}\text { Philanthropic } \\
\text { Responsibilities }\end{array}$ & .768 & .645 & .822 & 1.000 & 1.000 & .862 \\
\hline $\begin{array}{l}\text { Environmental } \\
\text { Preservation }\end{array}$ & .653 & .785 & .725 & .786 & .745 & .742 \\
\hline $\begin{array}{l}\text { Control of } \\
\text { Youth } \\
\text { Restiveness }\end{array}$ & .793 & .788 & .886 & .695 & & 1.000 \\
\hline
\end{tabular}

Source: Researchers Computation 2015

Table 1.2 above provides information on the degree of correlation between the independent variables and dependent variables used in the multiple regression analysis. The matrix shows that, the correlation between the variables is strong.

Further analyses to determine why these relationships exist were performed. The tables below present the reasons for the relationship and indeed how Corporate Social Responsibility is used as a strategy for environmental preservation and the control of youth restiveness.

Table 1.3. Environmental Preservation

\begin{tabular}{l|l|l|l|l}
\hline $\begin{array}{l}\text { Construct } \\
\text { Association }\end{array}$ & Alpha Level & Beta & P-value & Significant Yes/No \\
\hline $\begin{array}{l}\text { Company rises to } \\
\text { environmental } \\
\text { challenges }\end{array}$ & 0.05 & 1.510 & 0.000 & Yes \\
\hline $\begin{array}{l}\text { Protection of } \\
\text { community from } \\
\text { harmful production } \\
\text { materials }\end{array}$ & 0.05 & 1.546 & 0.000 & Yes \\
\hline $\begin{array}{l}\text { Enhancement of lives } \\
\begin{array}{l}\text { Environmental } \\
\text { Preservation }\end{array}\end{array} 0.05$ & 0.05 & 1.211 & 0.000 & Yes \\
\hline Soures & & 0.000 & Yes \\
\hline
\end{tabular}

Source: Researchers Computation 2015

In the table above, for all the constructs, there is a significant relationship between them and environmental preservation at Alpha $=0.05$ level of significant, with P-Value of 0.000

Table 1.4. Control of Youth Restiveness

\begin{tabular}{l|l|l|l|l}
\hline $\begin{array}{l}\text { Construct } \\
\text { Association }\end{array}$ & Alpha Level & Beta & P-value & Significant Yes/No \\
\hline $\begin{array}{l}\text { Award of } \\
\text { scholarship }\end{array}$ & 0.05 & 1.605 & 0.000 & Yes \\
\hline $\begin{array}{l}\text { Job creation and } \\
\text { employment }\end{array}$ & 0.05 & 1.622 & 0.000 & Yes \\
\hline $\begin{array}{l}\text { Support for cultural } \\
\text { programs and } \\
\text { sports }\end{array}$ & 0.0 & 1.541 & 0.000 & Yes \\
\hline $\begin{array}{l}\text { Building and } \\
\text { funding healthcare } \\
\text { projects }\end{array}$ & 0.05 & 1.473 & 0.000 & Yes \\
$\begin{array}{l}\text { Renovation of } \\
\text { schools and } \\
\text { vocational schools }\end{array}$ & 0.05 & 1.422 & 0.000 & Yes \\
\hline
\end{tabular}


Source: Researchers Computation 2015

In the table above, for all the constructs, there is a significant relationship between them and control of youth restiveness at Alpha $=0.05$ level of significant, with P-Value of 0.000

\section{Discussion}

Findings above revealed that the firms were able to preserve the environment in which they produce through corporate social responsibility and in particular, all the communities sampled confirmed that corporate social responsibility has become a culture for the multinational organizations sampled. For instance, the firms have well-constructed water effluence plants where factory wastes are discharged and properly managed, to prevent harmful substances been discharged to the communities, particularly in areas where indigenes are involved in agriculture. This has helped to preserve the communities and to a large extent therefore, respondents in the communities see the interventions as means through which youth restiveness have been greatly controlled.

Aside the above, it was revealed that firms sampled are always proactive on issues related to the environment, as managers within the firms take measures to prevent foreseeable problems and where they occur, do not waste time in developing compensation proposals for management approval to compensate individuals affected, thereby reducing their losses or returning them to a state as if nothing had happened. This again has helped in reducing youth restiveness and community hostilities.

Social investments have helped to preserve the communities and have enhanced lives of individuals and groups. This is in line with previous findings by researchers (Marioara, Gabriela and Daniel, 2013; Benabou \& Tirole, 2010; Sorsa, 2010). These scholars pointed that, compliance with ethical standards required by businesses and the protection of the rights and dignity of human beings by firms operating in communities, increased corporation credibility, help to position organizational strategies and enhanced the living standards of individuals in communities.

Furthermore, an assessment of the situation in the Niger Delta of Nigeria, in the study by Olawari \& Paki, 2011 and Okafor et al, 2008, both confirmed the empirical findings of the research and the truth that ethical standards and human right protection by firms enhance living standards and environmental sustainability.

Surely, where the firms failed to protect the environment they operate, tendency is that such firms breed hostility and youth restiveness between itself and the communities, with much more cost to pay in addressing them both in the short and long-term. Evidences are bound in many locations in Niger Delta in Nigeria.

Findings revealed that all the firms sampled have many social responsibilities they get involved in every year, which were indeed measurable targets approved for managers and have become their Key Performance Areas. Results are expected every year and reported in companies Annual Financial Reports. Such social investments are scholarship for indigenes from primary schools to universities, provision of portable water, building of clinics and provision of drugs in the clinics. Others are renovation of dilapidated schools and funding the establishment of Football Viewing Centres in some communities.

Corporate social responsibility is been used today to establish good rapport with the public. It is also used as pre-emption strategy by corporations to save their skin from unforeseen risks and corporate scandals, possible environmental accidents, governmental rules and regulations, protect eye-catching profits, brand differentiation and better relationship with employees based on volunteerism.

Corporations today readily publish their corporate social responsibility activities on their websites, sustainability reports and their advertisement campaigns in order to get the sympathy of their customers. This was observed in the Annual Financial Reports of the firms sampled.

\section{Conclusion and Recommendations}

Corporate social responsibility as becoming increasingly important by firms in Nigeria. It is voluntarily practiced in the nation. Many firms have now realized the usefulness of CSR as a strategy to gain competitive advantage and to boost company's image.

Again, customers as well as governments today are demanding more ethical behaviours from organizations. In response, multinational firms are volunteering themselves to incorporate it as part of the business strategies, mission statement and values in multiple domains, respecting labour and environmental laws, while taking care of the contradictory interest of various stakeholders.

Corporate social responsibility focuses on social investment in communities where firms produce, as it will be a disservice to firms to avoid giving back to these communities where they have remained prosperous. 
Research has shown that companies that care for the environment and exhibit good corporate social responsibility practices experienced increased consumer purchase preference in addition to increased investment appeal.

A socially responsible company tries to operate in a manner that causes minimal harm to the environment and tries to reduce its environmental impact as much as possible. Environmental preservation means that a company tries to manage the consumption of energy and non-renewable resources, as well as to reduce the amounts of waste they produce and dispose the waste in a safe and legal manner, which in return reduces their ecological footprint.

On the other hand, where firms are sensitive to the plight of the citizens by being proactive and empowering people living in the community sincerely and with utmost trustfulness, the chances are high that youth restiveness will reduce to the barest level and the community, as well as the firms will continue to prosper.

It is therefore recommended that government should develop a legal framework on corporate social responsibility policies and practices for firms particularly multinational companies, persuade firms to develop measurable corporate social responsibility initiatives and create a more favourable business environment for firms to thrive.

On the part of organizations in Nigeria, with the success stories of many multinational firms the world over, corporate social responsibility should be adopted as a strategy for market penetration, increase return-on-investment, image booster and to achieve competitive advantage. Particularly, they need to benchmark their activities in this area with their parent firms and firms in other countries.

\section{References}

AbdRahim, R., Jalaludin, F., \& Tajuddin, K. (2011). The importance of corporate social responsibility on consumer behaviour in Malaysia. Journal of Asian Academy of Management, 16(1), 119-139.

Akanbi, P., \& Ofoegbu, O. (2012). Impact of corporate social responsibility on bank performance in Nigeria. Journal of US-China Public Administration, 9(4), 374-383.

Amole, B., Adebiyi, S., \& Awolaja, A. (2012). Corporate social responsibility of Nigerian banks: A causal relationship. Research Journal of Finance and Accounting, 3(1), 8-17.

Bahadur, W., \& Waqqas, O. (2013). Corporate social responsibility for a sustainable business. Journal of Sustainable Society, 2(4), 92-97.

Benabou, R., \& Tirole, J. (2009). Individual and corporate social responsibility. Research group behaviour and experimental economics. Toulouse: Toulouse School of Economics.

Carroll, A. (1991). The pyramid of corporate social responsibility: Towards the moral management of organizational stakeholders. Business Horizons, 34, 39-48. https://doi.org/10.1016/0007-6813(91)90005-G

Carroll, A. (2008). A history of corporate social responsibility: Concepts and practices. In C, Andrew(Ed), Oxford handbook of corporate social responsibility. Oxford: Oxford University Press.

Clarkson, M. E. (1995). A stakeholder framework for analysing and evaluating corporate social responsibility performance. Academy Management Review, 20, 92-117. https://doi.org/10.5465/amr.1995.9503271994

Crane, A., \& Matten, D. (2009). Business ethics. Oxford: Oxford University.

Eccles, R., Ioannou, I., \& Serafeim, G. (2013). The impact of corporate sustainability on organizational processes and performance. Working paper, Harvard Business School.

Enderle, G., \& Tavis, A. (1998). A balanced concept of the firm and measurement of its long-term planning and performance. Journal of Business Ethics, 17(11), 1129-1143. Press. https://doi.org/10.1023/A:1005746212024

Freeman, E. (1984). Strategic management: A stakeholder approach. New York: Basic Books.

Lantos, G. (2001). The boundaries of strategic corporate social responsibility. Journal of Consumer Marketing, 28(7), 595-630. https://doi.org/10.1108/07363760110410281

Maldonado, G. G., Pinzon, C. S. Y., \& Lopez, T. G. C. (2016). Corporate social responsibility and business performance: The role of Mexican SMEs. International Journal of Asian Social Science, 6(10), 568-579. https://doi.org/10.18488/journal.1/2016.6.10/1.10.568.579

Marioara, I., Gabriela, C., \& Daniel, C. (2013). Factor analysis of corporate social responsibility as a key element for sustainable development. Napoca: University of Agricultural Sciences and Veterinary Medicine.

Mohr, L., \& Webb, D. (2005). The effects of corporate social responsibility and price on consumer responses. The Journal of Consumer Affairs, 39(1), 121-147. https://doi.org/10.1111/j.1745-6606.2005.00006.x

Muhammad, T., Naseer, A., Sheraz, A., \& Mehfooz, A. (2012). Corporate social responsibility: Definitions, concepts 
and scope. Universal Journal of Management and Social Sciences, 2(7), 41-52.

National Population Commission. (2006). Nigeria Population Census. Federal Republic of Nigeria.

Oginni, O. S., \& Omojowo, A. D. (2016). Sustainable development and corporate social responsibility in sub-Saharan Africa: Evidence from industries in Cameroon. Economies, 4(10), 1-15. https://doi.org/10.3390/economies4020010

Oh, W., \& Park, S. (2015). The relationship between corporate social responsibility and corporate financial performance in Korea. Emerging Markets Finance and Trade, 5(1), 85-94. https://doi.org/10.1080/1540496X.2015.1039903

Okafor, E., Hassan, A., \& Doyin, H. A. (2008). Environmental issues and corporate social responsibility: The Nigerian experience. Journal of Human Ecology, 23(2), 101-107. https://doi.org/10.1080/09709274.2008.11906060

Olawari, D., \& Paki, M. (2011). The rhetoric of corporate social responsibility in the Niger Delta. American International Journal of Contemporary Research, 1(3), 123-133.

Osemene, O. (2012). Corporate social responsibility practices in mobile telecommunications industry in Nigeria. European Journal of Business and Management, 4(8), 149-159.

Prahalad, C. (2005). The fortune at the bottom of the pyramid. New Jersey: Wharton School Publishing.

Sokefun, E. A. (2015). Corporate social responsibility and sustainable community development of multinational companies in South-West Nigeria. An unpublished PhD Thesis, Babcock University, Ilishan-Remo, Ogun State, Nigeria.

Sorsa, K. (2010). An empirical test of a cross-national model of corporate social responsibility. Journal of Business Ethics, 25, 33-51.

Strandberg, C. (2009). The role of human resource management in corporate social responsibility: Issues brief and roadmap. Canada: Strandberg Consulting.

United Nations Organization. (2013). A life of dignity for all: Accelerating progress towards the millennium development goals and advancing the United Nations Development agenda beyond 2015. New York: United Nations General Assembly.

Werhane, P., \& Freeman, R. (1999). Business ethics: The state of the art. International Journal of Management Review, I(1), 1-16. https://doi.org/10.1111/1468-2370.00002

Whelan, G. (2012). The political perspective of corporate social responsibility: A critical research agenda. Business Ethics Quarterly, 22(4), 709-737. https://doi.org/10.5840/beq201222445

Yusoff, W. F., \& Adamu, M. S. (2016). The relationship between corporate social responsibility and financial performance: Evidence from Malaysia. International Journal of Business Management, 10(4), 345-351.

\section{Copyrights}

Copyright for this article is retained by the author(s), with first publication rights granted to the journal.

This is an open-access article distributed under the terms and conditions of the Creative Commons Attribution license which permits unrestricted use, distribution, and reproduction in any medium, provided the original work is properly cited. 